\title{
Melanocortin Receptor Agonist (Corticotrophin) in Treatment of Refractory Diabetic Nephropathy
}

\author{
S.S.El-sayed, A.E.Mansour, A.T.Mahmoud, H.G.Abdelsalam, S.B.Hannalla and E.L.El-Shahawy
} Internal Medicine Dept., Faculty of Medicine, Benha Univ., Benha, Egypt

E-Mail: shimaasalah1986@gmail.com

\begin{abstract}
The aims of this study are to To assess the response and efficacy of melanocortin receptor agonist (ACTH) as a treatment for patients with refractory diabetic nephropathy. This study was performed on 50 diabetic patients who attended internal medicine department at banha university hospital. Patients with diabetic nephropathy presented with proteinuria more than $1 \mathrm{gm} / 24$ hour urine collection and who are not responding to anti proteinuric measures for at least one month of treatment treated with synthetic ACTH allowing a 6 months follow-up. Outcome. The primary endpoint was the percentage of patients achieving a complete remission $(<300 \mathrm{mg} / 24$ hours) within 6 months. Exploratory endpoints included the percentage of partial (50\% reduction) remissions, changes in Cr, eGFR. Results. After 6months of ACTH therapy, 29 patients $(58 \%)$ had achieved a complete remission and nine patients had achieved partial remission (18\%).Conclusion. ACTH gel stabilizes renal function and reduces urinary protein.
\end{abstract}

Keywords: ACTH, Diabetic nephropathy, Proteinuric nephropathy.

\section{Introduction}

Diabetes mellitus is a leading epidemic of the present world. It is considered the leading cause of death among ESRD patients. Kidney disease can be a devastating complication, as it is associated with significant reductions in both length and quality of life [1]. DN or DKD is a syndrome characterized by the presence of pathological quantities of urine albumin excretion, diabetic glomerular lesions, and reduction of glomerular filtration rate (GFR) in diabetics [2]. The overproduction of ROS is one of the hallmarks of diabetic kidney. ROS overproduction is the main cause of DN. Hyperglycemia induces nicotinamide adenine dinucleotide phosphate (NADPH) oxidase enzyme activity and is responsible for ROS overproduction [3]. Excess ROS mediates podocyte apoptosis and alteration in the slit diaphragm podocin protein, increases intracellular oxidative stress, mitochondrial injury, adenosine triphosphate (ATP) depletion, endothelial injury, renin angiotensin system (RAS) activation and increased epithelial-mesenchyme transition (EMT) with consequent fibrosis [4]. Transmembrane protein nephrin functions not only as the core component of the extracellular SD filtration network but also as a signaling scaffold via interactions at its short intracellular region [5].The different studies of kidney biopsies in patients with DN revealed the decreased glomerular expression of nephrin and the interrelation of these changes with the disorder of podocytes FP [6].

Focal defects of the SD due to nephrin dissociation from podocytes actin cytoskeleton with following nephrin separation and its excretion into urine (nephrinuria), are some of the mechanisms of proteinuria (PU) in various nephropathies. Nephrinuria as a marker of podocytes damage was found in DM [7]. ACTH is a tropic hormone produced by the anterior pituitary. The hypothalamic-pituitary axis controls it. ACTH regulates cortisol and androgen production [8]. The ACTH is synthesized by the corticotroph cells of the anterior pituitary gland. ACTH, is a 39-amino acid peptide, its sequence being highly conserved in mammals. The biological activity of the ACTH molecule depends on its first 24 amino-terminal amino acids [9]. In addition to the adrenal effects of ACTH, that is, its steroidogenic and adrenotropic activities, ACTH possesses a multifaceted extra-adrenal action that is mediated by the different MCRs present in the peripheral tissues and central nervous system. ACTH has a lipostatic effect and stimulates lipolysis. Indeed, ACTH deficiency leads to visceral obesity and causes conversion of brown adipose tissue to white adipose tissue. Moreover, ACTH administration to both healthy humans and patients with dyslipidemia lowers the levels of plasma lipids, including total cholesterol, LDL-cholesterol, phospholipids and triglycerides, which suggests a lipidlowering effect. Additionally, administration of the complete ACTH molecule (ACTH1-39) produces a marked and rapid increase in the levels of plasma insulin, which is consistent with an insulin secretagogue effect. This insulinotropic action is exerted by CLIP, also known as the ACTH18-39 fragment. ACTH also has various other peripheral endocrine activities: regulation of skin and hair pigmentation, modulation of sebaceous gland function, anti-inflammatory and immunomodulatory functions [10]. The ACTH treatment was found to have beneficial effects on glomerular function, such as increased glomerular filtration rate (GFR) and reduced proteinuria. Several successful studies followed wherein ACTH has been administered to steroid- and immunosuppressant-resistant patients with glomerular diseases affecting the podocytes [11].

Proteinuria reduction resulting in complete or partial remission following ACTH treatment has been shown in patients with idiopathic membranous nephropathy (iMN), idiopathic focal segmental glomerulosclerosis (FSGS), IgA nephropathy (IgAN), minimal change disease (MCD), and diabetic nephropathy (DN) [12].

\section{Material and methods}

This study was performed on 50 diabetic patients who attended internal medicine department at banha university hospital. Patients with age above 18 years old with diabetic nephropathy presented with proteinuria 
more than $1 \mathrm{gm} / 24$ hour urine collection and who are not responding to anti proteinuric measures for at least one month of treatment treated with synthetic ACTH allowing a 6 months follow-up. All participant were subjected to thorough history and clinical examination with special stress on duration of diabetes, the medications used by the patients, different Complications of diabetes.

Patients with estimated GFR less than 30 $\mathrm{mLs} / \mathrm{min}$ by the MDRD formula were excluded from the study. Patients with known primary or secondary membranous GN, primary or secondary focal segmental glomerulosclerosis, or other nondiabetic forms of glomerulopathy were also excluded. Patients with positive serology tests for hepatitis B or C antibodies, or bilharziasis were excluded.

Investigation was performed : Urine analysis, 24 hour urinary protein excretion, Spot urine sample for Protein creatinine ratio, Serum albumin, Lipid profile, Blood Urea - serum creatinine, eGFR by using MDRD, picture.

Serum uric acid, HbA1c, Complete blood

All patients were informed about the treatment and its effect and side effects and a written consent was taken. ACTH used is (synthetic analogue tetracosactide synacthen R ,Novartis pharmaceuticals ,Basal, Switzerland) . ACTH was given as intramuscular injection at a dosage $1 \mathrm{mg}$ twice weekly.

\subsection{Statistical analysis}

The clinical data were recorded on a report form. These data were tabulated and analysed using the computer program SPSS (Statistical package for social science) version 20.In the statistical comparison between the different groups, the significance of difference was tested using one of the following tests after establishing their non -normality by K-S test (One-Sample Kolmogorov-Smirnov Test) of normality.

1-Student's t-test and Mann-Whitney test:- Used to compare mean of two groups of quantitative data of parametric and non-parametric respectively.

2-Paired t test and willcoxon test: Used to compare mean of variables in different time periods of quantitative data of parametric and non-parametric respectively.

3-ANOVA test (F value) and kruskal-wallis test:-Used to compare mean of more than two groups of quantitative data of parametric and non-parametric respectively.

4-Inter-group comparison of categorical data was performed by using chi square test (X2-value) and fisher exact test (FET).

A $\mathrm{P}$ value $<0.05$ was considered statistically significant $(*)$ while $>0.05$ statistically insignificant $\mathrm{P}$ value $<0.01$ was considered highly significant $(* *)$ in all analyses.

\section{Results \\ The following results are reported in our results}

- There is a highly significant reduction of proteinuria in ACTH treated patients after 2 months, 4months and 6 months (p-value $<0.001$ ) by both $24 \mathrm{hr}$ protein in urine and protein creatinine ratio.

- The mean of proteinuria before treatment was $3.89 \pm 1.39 \mathrm{gm} / 24 \mathrm{hr}$ by $24 \mathrm{hr}$ protein in urine and $3840.1 \pm 1514.3 \mathrm{mg} / \mathrm{ml}$ protein creatinine ratio.

- The mean of proteinuria at 2 nd month of therapy was $2.56 \pm 1.24 \mathrm{gm} / 24 \mathrm{hr}$ by $24 \mathrm{hr}$ protein in urine and $2442.8 \pm 1228.6 \mathrm{mg} / \mathrm{ml}$ protein creatinine ratio.

- The mean of proteinuria at 4th month of therapy was $1.76 \pm 1.17 \mathrm{gm} / 24 \mathrm{hr}$ by $24 \mathrm{hr}$ protein in urine and $1637.96 \pm 1146.9 \mathrm{mg} / \mathrm{ml}$ protein creatinine ratio.

- The mean of proteinuria at 6th month of therapy was $0.97 \pm 1.04 \mathrm{gm} / 24 \mathrm{hr}$ by $24 \mathrm{hr}$ protein in urine and $914.2 \pm 1146.9 \mathrm{mg} / \mathrm{ml}$ protein creatinine ratio.

- There is a highly significant reduction of serum cholesterol and serum LDL in ACTH treated patient (p-value < 0.001).

- Mean pretreatment serum total cholesterol was $211.42 \pm 52.95 \mathrm{mg} / \mathrm{dL}$, while mean pretreatment serum LDL was $108.5 \pm 10.55 \mathrm{mg} / \mathrm{dL}$.

- Mean post treatment serum total cholesterol was $182.72 \pm 37.08 \mathrm{mg} / \mathrm{dL}$, while mean post treatment serum LDL was $98.26 \pm 8.36 \mathrm{mg} / \mathrm{dL}$.

- There is a highly significant improvement in serum albumin in ACTH treated patients (p-value $<0.001$ ).

- Mean pretreatment serum albumin was $2.96 \pm 0.41 \mathrm{gm}$ $/ \mathrm{dl}$, while post treatment serum albumin was $3.6 \pm 0.35$ $\mathrm{gm} / \mathrm{dl}$.

- There is an insignificant reduction of serum creatinine in ACTH treated patients ( $\mathrm{p}$-value >0.05).

- Mean pretreatment serum creatinine was $1.0(0.85$ 1.25) $\mathrm{mg} / \mathrm{dL}$, while mean post treatment serum creatinine was $1.0(0.9-1.1) \mathrm{mg} / \mathrm{dL}$.

- There was a significant reduction in serum uric acid in ACTH treated patients ( $\mathrm{p}$-value $<0.012$ ).

- Mean pretreatment serum uric acid was $6.47 \pm 1.02$ $\mathrm{mg} / \mathrm{dL}$, while mean post treatment serum uric acid was $6.29 \pm 1.0 \mathrm{mg} / \mathrm{dL}$

- There was an insignificant improvement in hemoglobin concentration, white blood cell count, platelet count in ACTH treated patients ( $\mathrm{p}$-value $>0.05$ ).

- Mean pretreatment hemoglobin concentration was $10.24 \pm 0.71 \mathrm{gm} / \mathrm{dl}$, while mean white blood cell count mean was $7.34 \pm 1.8 \times 109 / 1$, while mean platelet count was $224.88 \pm 47.59 \times 109 / 1$, while Mean post treatment hemoglobin concentration was $10.22 \pm 0.70 \mathrm{gm} / \mathrm{dl}$, while mean white blood cell count mean was $7.44 \pm 1.72 \times 109 /$ 1, while mean platelet count was $226 \pm 48.01 x$ 109 / 1 .

- There was an insignificant improvement in HBA1c in ACTH treated patients ( $\mathrm{p}$-value >0.05).

- Mean pretreatment HBA1c was $7.15 \pm 0.19 \%$, while mean post treatment HBA1c was $7.20 \pm 0.22 \%$.

- Adverse events associated with ACTH therapy were relatively minor and included pigmentation in hands and legs, hyperglycemia and hypokalemia. 
Table (1) The demographic and clinical characteristic of the outcome of ACTH therapy in patients with refractory diabetic nephropathy

\begin{tabular}{|c|c|c|c|c|c|c|c|c|}
\hline & \multicolumn{2}{|c|}{$\begin{array}{l}\text { Complete } \\
\text { remission } \\
\end{array}$} & \multicolumn{2}{|c|}{ Partial remission } & \multicolumn{2}{|c|}{$\begin{array}{l}\text { Limited } \\
\text { response }\end{array}$} & \multirow[t]{2}{*}{$\begin{array}{l}\text { Statistical test } \\
\text { (FET) }\end{array}$} & \multirow[t]{2}{*}{$P$ value } \\
\hline & No (29) & $\%$ & No (9) & $\%$ & No (12) & $\%$ & & \\
\hline Age & & & & & & & & \\
\hline Mean \pm SD & \multicolumn{2}{|c|}{$45.0 \pm 5.67$} & \multicolumn{2}{|c|}{$41.67 \pm 7.98$} & \multicolumn{2}{|c|}{$48.5 \pm 7.78$} & $\mathrm{~F}=2.77$ & 0.07 \\
\hline Range & \multirow{2}{*}{\multicolumn{2}{|c|}{$36-56$}} & \multicolumn{2}{|c|}{$33-53$} & \multicolumn{2}{|c|}{$34-59$} & & \\
\hline Gender & & & & & & & & \\
\hline Male & 12 & 41.4 & 6 & 66.7 & 4 & 33.3 & $\mathrm{X} 2=2.51$ & 0.29 \\
\hline Female & 17 & 58.6 & 3 & 33.3 & 8 & 66.7 & & \\
\hline \multicolumn{9}{|l|}{ Edema } \\
\hline Yes & 27 & 93.1 & 9 & 100 & 11 & 91.7 & 0.72 & 1.0 \\
\hline No & 2 & 6.9 & 0 & 0.0 & 1 & 8.3 & & \\
\hline \multicolumn{9}{|c|}{ Pleural effusion } \\
\hline Yes & 11 & 37.9 & 6 & 66.7 & 7 & 58.3 & 2.9 & 0.29 \\
\hline No & 18 & 62.1 & 3 & 33.3 & 5 & 41.7 & & \\
\hline \multicolumn{9}{|l|}{ Ascites } \\
\hline Yes & 8 & 27.6 & 2 & 22.2 & 3 & 25.0 & 0.17 & 1.0 \\
\hline No & 21 & 72.4 & 7 & 77.8 & 9 & 75.0 & & \\
\hline \multicolumn{9}{|c|}{ Hypertension } \\
\hline Yes & 7 & 24.1 & 1 & 11.1 & 1 & 8.3 & 1.41 & 0.52 \\
\hline No & 22 & 75.9 & 8 & 88.9 & 11 & 91.7 & & \\
\hline \multicolumn{9}{|c|}{ Complication No (\%) } \\
\hline Pigmentatiol & 5 & 17.2 & 1 & 11.1 & 1 & 8.3 & & \\
\hline
\end{tabular}

\section{I-Complete remission}

29 patient (12 male and 17 female) achieved complete remission with age ranged from 36 to 56 year.

27 had edema lower limb, while 11 had pleural effusion and only 8 patients had ascites. 7 patients were hypertensive.

5 had hyperpigmentation.

\section{II-partial remission}

9 patients (6 male and 3 female) achieved partial remission with age range from 33 to 53 year.
All of the patients were edematous, while 6 patients had pleural effusion, and only two patients had ascites. Only 1 patients was hypertensive.

Only 1 patient had hyperpigmentation.

\section{III-limited response}

12 patients developed limited response (4 male and 8 female)with age ranged from 34 to 59year.

11 patient were edematous, 7 patients had effusion, and only 3 had ascites. 1 patient was hypertensive.

Only one patient had hyperpigmentation.

Table (2) The biochemical characteristic of the outcome of ACTH therapy in patients with refractory diabetic nephropathy.

\begin{tabular}{|c|c|c|c|c|c|c|c|c|}
\hline & \multicolumn{2}{|c|}{ Complete remission } & \multicolumn{2}{|c|}{ Partial remission } & \multicolumn{2}{|c|}{ Limited response } & \multirow{3}{*}{$\begin{array}{c}\begin{array}{c}\text { Statistical } \\
\text { test (F) }\end{array} \\
6.05\end{array}$} & \multirow{2}{*}{ P value } \\
\hline & & & & & & & & \\
\hline++ & 12 & 41.4 & 1 & 11.1 & 3 & 25.0 & & 0.43 \\
\hline+++ & 8 & 27.6 & 6 & 66.7 & 5 & 41.7 & & \\
\hline++++ & 8 & 27.6 & 2 & 22.2 & 4 & 33.3 & & \\
\hline+++++ & 1 & 3.4 & 0 & 0.0 & 0 & 0.0 & & \\
\hline Cholesterol before & $205.83 \pm 56.73$ & $124-370$ & $\begin{array}{c}237.33 \pm 30 \\
.79\end{array}$ & $178-279$ & $205.5 \pm 54.2$ & $122-321$ & 1.33 & 0.27 \\
\hline Cholesterol after & $177.83 \pm 39.34$ & $119-301$ & $\begin{array}{c}200.56 \pm 23 \\
.29\end{array}$ & $160-250$ & $181.17 \pm 38.29$ & $124-259$ & 1.32 & 0.28 \\
\hline LDL before & 107.28 & 9.71 & 112.44 & 11.84 & 108.5 & 11.73 & $\mathrm{~F}=0.82$ & 0.45 \\
\hline LDL after & 97.9 & 8.18 & 100.11 & 6.77 & 97.75 & 10.2 & $\mathrm{~F}=0.26$ & 0.77 \\
\hline $\begin{array}{l}\text { Initial creatinine } \\
\text { Median (IQR) }\end{array}$ & \multicolumn{2}{|c|}{$1.0(0.8-1.6)$} & \multicolumn{2}{|c|}{$1.2(0.8-1.95)$} & \multicolumn{2}{|c|}{$1.0(0.83-1.08)$} & $\mathrm{KW}=1.33$ & 0.51 \\
\hline $\begin{array}{l}\text { Follow up creat } \\
\text { Median (IQR) }\end{array}$ & \multicolumn{2}{|c|}{$1.0(0.9-1.15)$} & \multicolumn{2}{|c|}{$1.0(0.75-1.55)$} & \multicolumn{2}{|c|}{$0.95(0.83-1.0)$} & $K W=2.99$ & 0.23 \\
\hline E GFR before & $66.51 \pm 27.22$ & $20-120$ & $\begin{array}{c}74.37 \pm 41 \\
86\end{array}$ & $\begin{array}{l}22.3- \\
163.9\end{array}$ & $76.6 \pm 25.8$ & $\begin{array}{c}51- \\
147.06\end{array}$ & $\mathrm{~F}=0.58$ & 0.56 \\
\hline
\end{tabular}


Table (2) Continue

\begin{tabular}{|c|c|c|c|c|c|c|c|c|}
\hline E GFR after & $67.96 \pm 15.68$ & $\begin{array}{l}34.9- \\
100.6\end{array}$ & $\begin{array}{c}85.97 \pm 39 . \\
42\end{array}$ & $32-152.3$ & $77.31 \pm 21.77$ & $\begin{array}{c}58.8- \\
123.05\end{array}$ & $\mathrm{~F}=2.36$ & 0.11 \\
\hline Albumin before & $2.98 \pm 0.42$ & $2.1-3.5$ & $2.83 \pm 0.4$ & $2.1-3.4$ & $3.02 \pm 0.43$ & $2.5-3.6$ & $\mathrm{~F}=0.56$ & 0.57 \\
\hline Albumin after & $3.75 \pm 0.29$ & $2.6-4.2$ & $3.49 \pm 0.32$ & $3.1-4$ & $3.33 \pm 0.34$ & $2.9-3.9$ & $F=8.66$ & $0.001 * *$ \\
\hline HbA1c before & 7.17 & 0.19 & 7.11 & 0.15 & 7.15 & 0.21 & $\mathrm{~F}=0.32$ & 0.73 \\
\hline HbA1c 4m & 7.18 & 0.21 & 7.17 & 0.13 & 7.2 & 0.30 & $\mathrm{~F}=0.06$ & 0.94 \\
\hline HbA1c 6m & 7.20 & 0.22 & 7.17 & 0.15 & 7.22 & 0.27 & $F=0.13$ & 0.88 \\
\hline Uric acid before & 6.57 & 1.09 & 6.2 & 0.66 & 6.43 & 1.12 & $F=0.44$ & 0.65 \\
\hline Uric acid after & 6.36 & 1.07 & 6.06 & 0.60 & 6.33 & 1.10 & $\mathrm{~F}=0.31$ & 0.74 \\
\hline Hb before & 10.11 & 0.73 & 10.14 & 0.71 & 10.64 & 0.57 & $F=2.64$ & 0.082 \\
\hline Hb after & 10.08 & 0.72 & 10.2 & 0.67 & 10.58 & 0.59 & $\mathrm{~F}=2.28$ & 0.11 \\
\hline WBC before & 7.41 & 1.93 & 6.98 & 1.32 & 7.47 & 1.87 & $\mathrm{~F}=0.23$ & 0.80 \\
\hline WBC after & 7.45 & 1.78 & 7.11 & 1.44 & 7.66 & 1.87 & $\mathrm{~F}=0.25$ & 0.78 \\
\hline PLT before & 214.21 & 41.47 & 244.22 & 58.56 & 236.17 & 49.73 & $\mathrm{~F}=1.88$ & 0.17 \\
\hline PLT after & 214.69 & 40.09 & 243.78 & 61.77 & 240 & 50.93 & $\mathrm{~F}=2.01$ & 0.15 \\
\hline $\begin{array}{l}\text { Complication No } \\
(\%)\end{array}$ & 2 & 6.9 & 0 & 0.0 & 0 & 0.0 & $\mathrm{FET}=$ & 0.60 \\
\hline $\begin{array}{l}\text { Decrease K } \\
\text { Hyperglycaemia }\end{array}$ & 2 & 6.9 & 0 & 0.0 & 3 & 25.0 & 4.63 & \\
\hline
\end{tabular}

\section{I-Complete remission}

Albuminuria ranged from ++ to +++++ .

Serum cholesterol before therapy ranged 124$370 \mathrm{mg} / \mathrm{dL}$ and mean $205.83 \pm 56.73 \mathrm{mg} / \mathrm{dL}$, but after therapy ranged $119-301 \mathrm{mg} / \mathrm{dL}$ and mean $177.83 \pm 39.34$ $\mathrm{mg} / \mathrm{dL}$.

Serum albumin before therapy ranged $2.1-3.5 \mathrm{~g} / \mathrm{dL}$ and mean $2.98 \pm 0.42 \mathrm{~g} / \mathrm{dL}$, but

after therapy serum albumin ranged 2.6-4.2 $\mathrm{g} / \mathrm{dL}$ and mean $3.75 \pm 0.29 \mathrm{~g} / \mathrm{dL}$.

There is a highly significant improvement of serum albumin in ACTH treated patients ( $\mathrm{p}$-value $<0.001$ ).

There is an insignificant reduction of serum creatinine in ACTH treated patients ( $\mathrm{p}$-value >0.05) .

There is an insignificant improvement in e GFR in ACTH treated patients (p-value >0.05) .

2 of the patients had hypokalemia, 2 had impaired blood glucose control.

\section{II-partial remission}

Albuminuria ranged from ++ to ++++ .

Serum cholesterol before therapy ranged 178-279 $\mathrm{mg} / \mathrm{dL}$ and mean $237.33 \pm 30.79$, but after therapy ranged $160-250 \mathrm{mg} / \mathrm{dL}$ and mean $200.56 \pm 23.29 \mathrm{mg} / \mathrm{dL}$.

Serum albumin before therapy ranged $2.1-3.4 \mathrm{~g} / \mathrm{dL}$ and mean $2.83 \pm 0.4 \mathrm{~g} / \mathrm{dL}$, but after therapy serum albumin ranged 3.1-4 g/dL and mean $3.49 \pm 0.32 \mathrm{~g} / \mathrm{dL}$.

\section{III-limited response}

Albuminuria ranged from +++ to ++++ .

Serum cholesterol ranged $122-321 \mathrm{mg} / \mathrm{dL}$ and mean $205.5 \pm 54.2$, but after therapy ranged $124-259 \mathrm{mg} / \mathrm{dL}$ and mean $181.17 \pm 38.29 \mathrm{mg} / \mathrm{dL}$.

Serum albumin before therapy ranged $2.5-3.6 \mathrm{~g} / \mathrm{dL}$ and mean $3.02 \pm 0.43 \mathrm{~g} / \mathrm{dL}$, but after therapy serum albumin ranged 2.9-3.9 g/dL and mean $3.33 \pm 0.34 \mathrm{~g} / \mathrm{dL}$.

3 patient had impaired blood glucose control.

Table (3) The proteinuria outcome of ACTH therapy in patients with refractory diabetic nephropathy.

\begin{tabular}{|c|c|c|c|c|c|c|c|c|}
\hline \multirow[b]{2}{*}{24 hr protein in urine } & \multicolumn{2}{|c|}{ Complete remission } & \multicolumn{2}{|c|}{ Partial remission } & \multicolumn{2}{|c|}{ Limited response } & \multirow{2}{*}{$\begin{array}{c}\text { Statistical } \\
\text { test }(\mathrm{F})\end{array}$} & \multirow[t]{2}{*}{ P value } \\
\hline & $\begin{array}{l}\text { Mean } \pm \\
\text { SD }\end{array}$ & Range & $\begin{array}{l}\text { Mean } \pm \\
\text { SD }\end{array}$ & Range & $\begin{array}{l}\text { Mean } \pm \\
\text { SD }\end{array}$ & Range & & \\
\hline Initial & $3.69 \pm 1.43$ & $1.3-6$ & $4.22 \pm 1.35$ & $2.3-6.3$ & $4.12 \pm 1.37$ & $1.7-5.6$ & 0.71 & 0.5 \\
\hline 2 months & $2.06 \pm 1.07$ & $0.8-4$ & $3.19 \pm 1.16$ & $1.7-5.3$ & $3.3 \pm 1.17$ & $1.2-4.6$ & 7.07 & $0.002 * *$ \\
\hline 4 months & $1.17 \pm 0.87$ & $0.32-3.7$ & $2.33 \pm 1.19$ & $0.97-4.4$ & $2.73 \pm 0.99$ & $1.0-3.9$ & 13.12 & $<0.001 * *$ \\
\hline 6 months & $0.37 \pm 0.68$ & $0.11-3.0$ & $1.3 \pm 0.90$ & $0.37-2.8$ & $2.17 \pm 0.70$ & $0.95-2.9$ & 27.36 & $<0.001 * *$ \\
\hline $\begin{array}{l}\text { Protein creatinine } \\
\text { ratio before }\end{array}$ & 3549.14 & 1399.16 & 4538.89 & 1927.96 & 4019.17 & 1367.62 & $\mathrm{~F}=1.62$ & 0.21 \\
\hline $\begin{array}{l}\text { Protein creatinine } \\
\text { ratio after } 2 \mathrm{~m}\end{array}$ & 1953.79 & 1056.32 & 3012.22 & 1160.87 & 3197.5 & 1177.73 & $\mathrm{~F}=6.85$ & $0.002 * *$ \\
\hline $\begin{array}{l}\text { Protein creatinine } \\
\text { ratio after } 4 \mathrm{~m}\end{array}$ & 1072.52 & 838.96 & 2178.89 & 1189.32 & 2598.75 & 974.55 & $\mathrm{~F}=13.02$ & $<0.001 * *$ \\
\hline $\begin{array}{l}\text { Protein creatinine } \\
\text { ratio after } 6 \mathrm{~m}\end{array}$ & 341.03 & 672.79 & 1207.78 & 872.39 & 2079.17 & 686.75 & $\mathrm{~F}=26.09$ & $<0.001 * *$ \\
\hline
\end{tabular}

Comparison between complete, partial remission and limited response there is a significant reduction of proteinuria in ACTH treated patients after 2 months (pvalue $=0.002$ ), and highly significant reduction of 


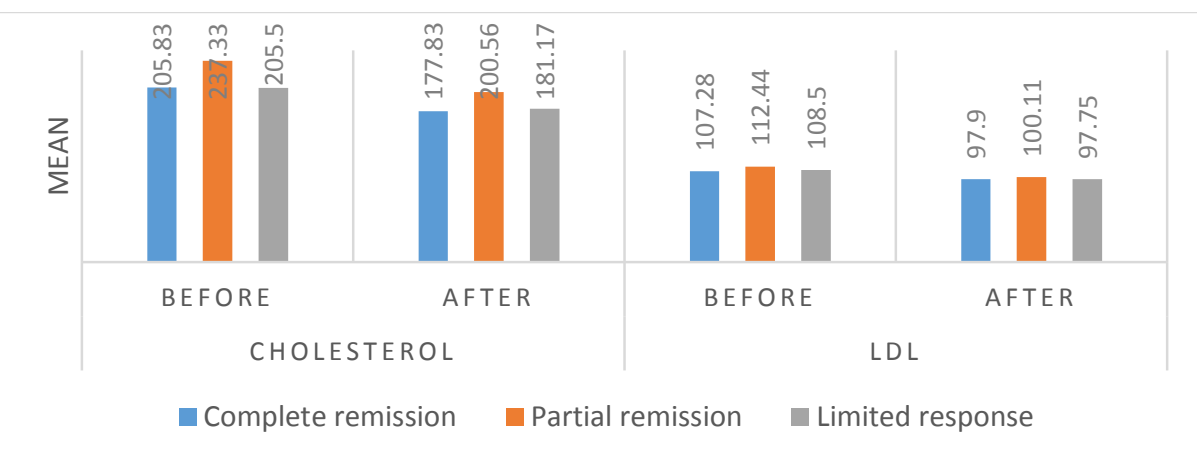

Fig (1) The serum cholesterol and serum LDL outcome of ACTH therapy in patients with refractory diabetic nephropathy.

Figure showed that there was reduction of the mean of serum cholesterol and serum LDL in complete remission, partial remission and limited response.

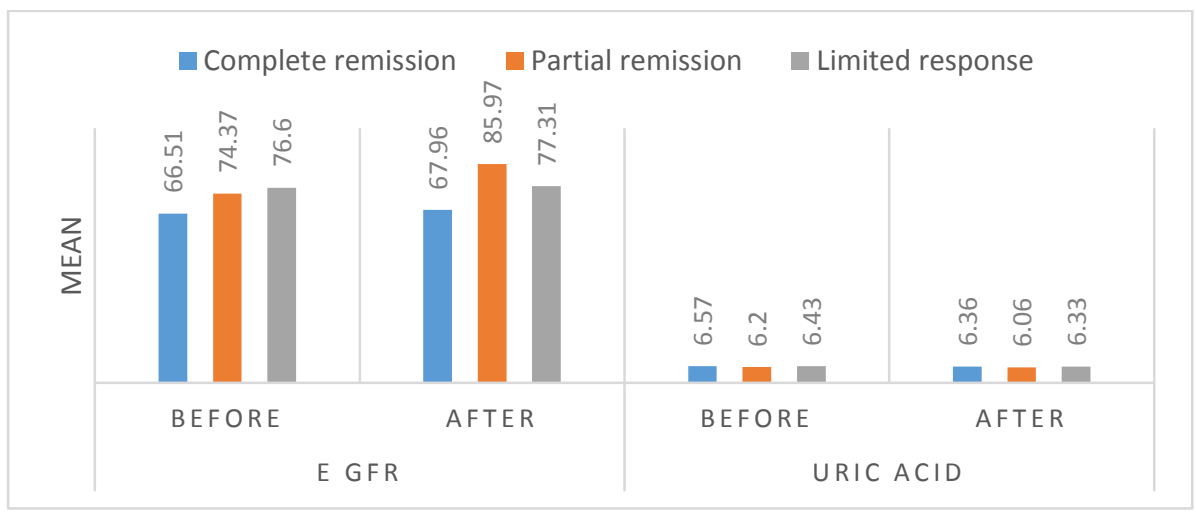

Fig (2) The eGFR and serum uric acid outcome of ACTH therapy in patients with refractory diabetic nephropathy.

Figure showed that there was insignificant improvement of eGFR among the 3 groups (complete, partial remission and limited response).
Figure showed that there was insignificant reduction of serum uric acid among the 3 groups (complete, partial remission and limited response).

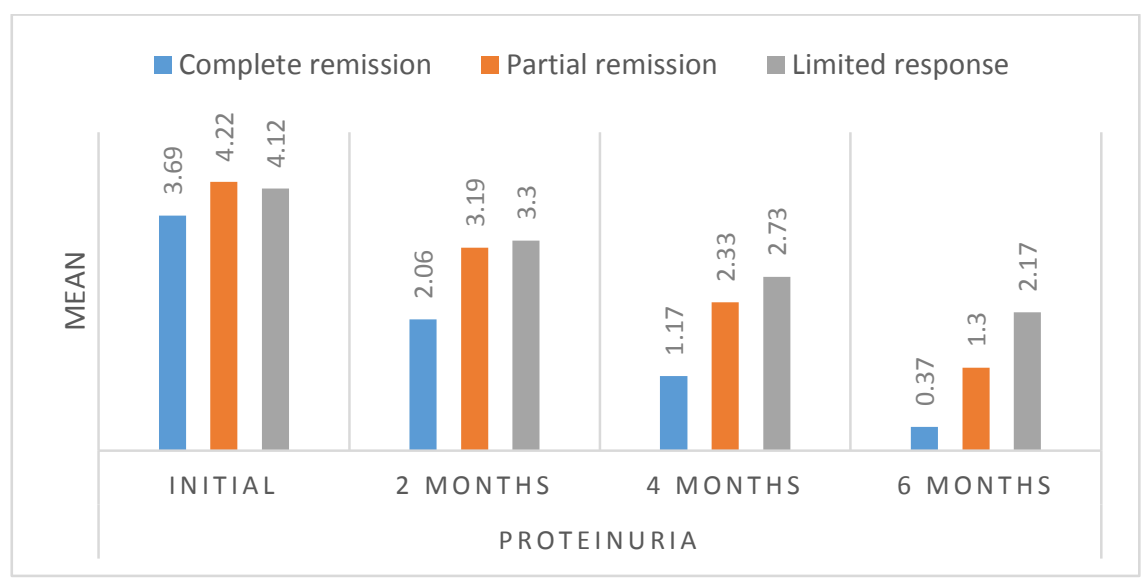

Fig (3) The proteinuria outcome of ACTH therapy in patients with refractory diabetic nephropathy by $24 \mathrm{hr}$ protein in urine. 
Figure showed that there was reduction of the mean of proteinuria by $24 \mathrm{hr}$ protein in urine among the 3 groups (complete, partial remission and limited response).

\section{Discussion}

Diabetic nephropathy is characterized by expansion of mesangial matrix, thickening of the basement membranes, and development of sclerosis in areas of reduced podocyte density. The progressive loss of podocyte function is increasingly being recognized as a central pathogenic event in diabetic nephropathy [13].

The mechanisms contributing to progressive loss of podocytes include hyperglycemia, angiotensin II and aldosterone induced oxidant injury, and increased production of TGF $\beta$ [14].

Clinical studies have examined the utility of ACTH in the treatment of the nephrotic syndrome from a variety of different glomerulopathies [15].

Proteinuria reduction resulting in complete or partial remission following ACTH treatment has been shown in patients with iMN, idiopathic FSGS, IgA nephropathy, MCD, and DN [16].

Potential mechanisms of action of ACTH include steroid-independent effects through the melanocortin system and steroid-related effects [17].

ACTH signals through five widely distributed melanocortin receptors that have recently been demonstrated in glomerular podocytes. The observation that melanocortin receptors are present in podocytes raises the possibility that ACTH alters glomerular permeability by modifying podocyte function. The melanocortin receptor 1 have been shown in podocytes, glomerular endothelial cells, and mesangial cells, and an MC1R agonist resulted in significantly reduced proteinuria in the passive Heymann nephritis animal model [18].

The fact that melanocortin receptor 1 (MC1R) was found to be the most abundant ACTH receptor in the glomeruli, in combination with it being the only MCR that is augmented in nephrotic syndrome, confirm its role as being the receptor responsible for the beneficial effects of ACTH seen in patients with nephrotic syndrome.previous studies indicated that MC1R signaling is favorable to podocyte function and when exposed to PAN in culture, podocytes upregulated MC1R at both the mRNA and protein level [19].

MC1R may be a promising therapeutic target in the treatment of nephrotic patients and thereby eliminate the unwanted side effects of ACTH, which acts via the MC2R [20].

We conducted a clinical prospective study evaluating the effect of treatment with melanocortin receptor agonis in 50 patients with refractory diabetic nephropathy conducted in Benha University Hospital.

Treatment with angiotensin-converting enzyme inhibitors or angiotensin-receptor blockers remained unmodified. All patients had received ACTH synthetic form at a dose of $1 \mathrm{mg}$ intramuscularly twice per week for 6 months.
In our study we found that ACTH induced a complete or partial remission of proteinuria in $76 \%$ of patients. 29 patients $(58 \%)$ had achieved a complete remission and nine patients had achieved partial remission $(18 \%)$.

29 patient (12 male and 17 female) achieved complete remission. serum albumin before therapy ranged 2.1-3.5 g/dL and mean $2.98 \pm 0.42 \mathrm{~g} / \mathrm{dL}$, but after therapy serum albumin ranged 2.6-4.2 $\mathrm{g} / \mathrm{dL}$ and mean $3.75 \pm 0.29 \mathrm{~g} / \mathrm{dL}$. with serum cholesterol before therapy ranged $124-370 \mathrm{mg} / \mathrm{dL}$ and mean $205.83 \pm 56.73 \mathrm{mg} / \mathrm{dL}$, but after therapy ranged $119-301 \mathrm{mg} / \mathrm{dL}$ and mean $177.83 \pm 39.34 \mathrm{mg} / \mathrm{dL}$.

9 patients (6 male and 3 female) achieved partial remission. serum albumin before therapy ranged 2.1-3.4 $\mathrm{g} / \mathrm{dL}$ and mean $2.83 \pm 0.4 \mathrm{~g} / \mathrm{dL}$, but after therapy serum albumin ranged $3.1-4 \mathrm{~g} / \mathrm{dL}$ and mean $3.49 \pm 0.32 \mathrm{~g} / \mathrm{dL}$. serum cholesterol before therapy ranged 178-279 $\mathrm{mg} / \mathrm{dL}$ and mean $237.33 \pm 30.79$, but after therapy ranged $160-250 \mathrm{mg} / \mathrm{dL}$ and mean $200.56 \pm 23.29 \mathrm{mg} / \mathrm{dL}$.

We further demonstrated that ACTH appears to have favorable effects with sustained reductions in proteinuria and stable renal function during the study.

There was also highly significant reduction in serum cholesterol. And there was highly significant improvement in serum albumin.

There is an insignificant reduction of serum creatinine in ACTH treated patients.

Adverse events associated with ACTH therapy were relatively minor and included pigmentation in hands and legs, impaired glucose tolerance and hypokalemia.

Our observations are concordant with previously published reports from (Tumlin et al., 2013) [14]. using ACTH gel daily subcutaneous in patients with refractory nephrotic syndrome secondary to diabetic nephropathy.

Our observations are concordant with the results, of the successful experiences of (Anna-Lena Berg and Arnadottir 2004) [21] in treating nephrotic syndromes. two of the 23 cases presented in their series were nephrotic syndrome due to diabetic nephropathy. Both developed complete remission with sustained serum creatinine and improvement of serum albumin.

We observed a decrease in serum total cholesterol and serum LDL. Our observations are concordant with the results of (Arvind Madan et al., 2016) [22] as There was a mean reduction in total cholesterol.

The reduction in serum lipids occurred not only in remitting patients. this may be in agreement with some evidence suggesting that ACTH may affect serum lipids independently of changes in proteinuria. A possible interpretation is that by modifying apolipoprotein metabolism, ACTH restores levels of certain apolipoproteins, including apolipoprotein $\mathrm{E}$ or apolipoprotein J. [10]. There was improvement of serum albumin. Our observations are concordant with the results, of the successful experiences of (Anna-Lena Berg and Arnadottir 2004) as The median serum albumin concentration was $1.9(1.0-2.3) \mathrm{g} / \mathrm{dl}$ before treatment, $3.5(1.7-4.3) \mathrm{g} / \mathrm{l}$ after treatment [21]. 
InT2DM and biopsy-proven DN the albumin level had a significant inverse correlation with proteinuria, cholesterol, and histopathological damage, including glomerular lesions, interstitial inflammation, and arteriolar hyalinosis [23]. In our study there was decrease in serum uric acid.

ACTH and cortisone have been shown to have uricosuric effects, and the increase in urinary uric acid: creatinine ratio [24].

SUA levels correlated positively with urinary albumin-creatinine ratio [25].

Cross-sectional study found that compared to microalbuminuria group, the level of SUA was high in macroalbuminuric diabetic patients [26]. A prospective study in Japan reported that while there was no relationship between SUA and eGFR, low and high SUA levels were independent predictors of progression of albuminuria in diabetic patients [27].

In our study there was insignificant impairment in HBA1c.

The steroidogenic melanocortin peptide ACTH has been labeled to potentially generate steroid like side effects and incur cushingoid symptoms, including visceral obesity, hyperglycemia, osteoporosis. the steroid like side effects or Cushingoid symptoms seem to be mild at the clinical doses of ACTH [28].

Our observations are concordant with previously published reports from (Tumlin et al., 2013) The average 24 hour urine protein excretion was significantly reduced , associated with stabilized kidney function and no deterioration of diabetes. Only 2 of 18 patients (11\%) required reduction in ACTH dose secondary to hyperglycemia, suggesting that ACTH therapy, totally different from glucocorticoid therapy, is safe for patients with diabetes [14].

ACTH and related peptides can influence B-cell function through activation of the MC2-R, leading to the activation of PKA and increased $\mathrm{Ca} 2+$ entry through voltage dependent $\mathrm{Ca} 2+$ channels. The physiological relevance of these effects is most likely to be in the fine control of -cell function, in a system where ACTH acts along with other biologically active peptides that are released from peptidergic neurons terminating within the islets of Langerhan [29].

\section{Conclusions}

ACTH induced a complete or partial remission of proteinuria in $76 \%$ of patients. 29 patients $(58 \%)$ had achieved a complete remission and nine patients had achieved partial remission (18\%) .

We further demonstrated that ACTH appears to have favorable effects with sustained reductions in proteinuria and stable renal function during the study.

There is a highly significant reduction of proteinuria in ACTH treated patients after 2 months, 4months and 6 months ( $\mathrm{p}$-value $<0.001$ ) by both $24 \mathrm{hr}$ protein in urine and protein creatinine ratio.

\section{References}

[1] P. McFarlane, D. Cherney, R. E,Chronic Kidney Disease in Diabetes Diabetes Canada Clinical Practice Guidelines Expert Committee: Can J Diabetes , Vol.4, PP.201-209, 2018.

[2] S.C.Lim,J.J.Liu,T.Subramaniam ,Elevated circulating alpha-klotho by angiotensin II receptor blocker losartan is associated with reduction of albuminuria in type 2 diabetic patients. J Renin Angiotensin Aldosterone Syst , Vol.3, PP.487490,2014.

[3] F.Giacco,M.Brownlee, Oxidative stress and diabetic complications, Vol.2, PP.1850-1870, 2010.

[4] S.Eid,S.Boutary,K.Braych,mTORC2 Signaling Regulates Nox4-Induced Podocyte Depletion in Diabetes. Antioxid Redox Signal, Vol.5, PP.703717,2016.

[5] C.E.Martin,N.Jones,Nephrin Signaling in the Podocyte: An Updated View of Signal Regulation at the Slit Diaphragm and Beyond. Front Endocrinol, Vol.3, PP.275-309,2018.

[6] B.Jim,M.Ghanta,A.Qipo, Dysregulated nephrin in diabetic nephropathy of type 2 diabetes: A cross Sectional study. PLoS ONE, Vol.3, PP.455460,2012.

[7] N.G.DPK,B.C.Tai,E.Tan,Nephrinuria associates with multiple renal traits in type 2 diabetes. Nephrol Dial Transplant; 26, Vol.6, PP.25082514,2010.

[8] N.A.Shumiloff,W.M .Lam,K.B.Manasco , Adrenocorticotropic hormone for the treatment of West Syndrome in children. Ann Pharmacother, Vol.2, PP.744-754,2013.

[9] P.Lowry,60 YEARS OF POMC: Purification and biological characterisation of melanotrophins and corticotrophins. J Mol Endocrinol, Vol.4, PP.500$519,2016$.

[10] Cong,Rujon ,The renaissance of corticotropin therapy in proteinuric nephropathies. Nature Reviews Nephrology, Vol.8, p.p122-128, 2011.

[11] P.Lorusso,A.Bottai,E.Mangione, Low-dose synthetic adrenocorticotropic hormone-analog therapy for nephrotic patients: results from a singlecenter pilot study. Int J Nephrol Renovasc Dis , Vol.6, PP.190-199,2015.

[12] M.A.Hladunewich,D.Cattran,L.H.Beck, A pilot study to determine the dose and effectiveness of adrenocorticotrophic hormone (H.P. Acthar® Gel) in nephrotic syndrome due to idiopathic membranous nephropathy. Nephrol Dial Transplant, Vol.1, PP.240-245,2014.

G.Wolf,S.Chen, "Fromthe periphery of the glomerular capillary wall toward the center of disease: podocyte injury comes of age in diabetic nephropathy," Diabetes, Vol. 54, PP. 16261634,2005 .

[13] JA.Tumulin, CM.Galphin, BH.Rovin , Advanced diabetic nephropathy with nephrotic range proteinuria: a pilot study of the long-term efficacy of subcutaneous ACTH gel on proteinuria, 
progression of CKD, and urinary levels of VEGF and MCP-1. J Diabetes Res, Vol.8, PP.1155$1163,2013$.

[14] R. Gong , "The renaissance of corticotropin therapy in proteinuric nephropathies," Nature Reviews Nephrology, Vol. 8, PP. 122-128,2012.

[15] K.V. Lieberman, L. Ettinger, C. Picarelli,Adrenocorticotropic hormone for steroidresistant and oral steroid-intolerant children with minimal change nephrotic syndrome. Gong $\mathrm{R}$ (2014): Leveraging melanocortin pathways to treat glomerular diseases. Adv Chronic Kidney, Vol. 10 (2) , PP. 122-128,2014.

[16] A. Lindskog, K. Ebefors, M.E. Johansson, Melanocortin 1 receptor agonists reduce proteinuria. the American Society of Nephrolog : JASN J., Vol.21, PP.1290-1298, 2010.

[17] J. Elvin, L. Buvall, A. Lindskog Jonsson, Melanocortin 1 receptor agonist protects podocytes through catalase and RhoA activation. Am J Physiol Renal Physiol., Vol. 310, PP.F846-856, 2015.

[18] T.Benned-Jensen, J.Mokrosinski \& $\mathrm{M}$ M.Rosenkilde , The E92K Melanocortin 1 Receptor Mutant Induces cAMP Production and Arrestin Recruitment but Not ERK Activity Indicating Biased Constitutive Signaling. PLoS One 6, e24644, https://doi.org/10.1371/ journal.pone., Vol.28,PP.246-248,2011.

[19] Anna-Lena Berg and Margret Arnadottir , ACTHinduced improvement in the nephrotic syndrome in patients with a variety of diagnoses. Nephrology Dialysis Transplantation; Vol 19, PP.13051307,2004.

[20] Arvind Madan, Snezana Mijovic-Das, Ana Stankovi, Acthar gel in the treatment of nephrotic syndrome: a multicenter retrospective case series. BMC Nephrology., Vol.17, PP.37, 2016.

[21] J.Zhang, R.Zhang, Y.Wang, The Level of Serum Albumin Is Associated with Renal Prognosis in Patients with Diabetic Nephropathy. J Diabetes., Vol.78, PP.258-26004,2019.

[22] F.Marson, Effect of ACTH and sodium salicylate on the urinary uric acid: creatinine ratio; and circulating eosinophils in man.Quart. J. Med., Vol.22, PP.331-335,1953.

[23] S.Bonakdaran, M.Hami, MT.Shakeri , Hyperuricemia and albuminuria in patients with type 2 diabetes mellitus. Iranian J Kidney., Vol.5(1), PP.21-24,2011.

[24] CC.Liang, PC.Lin, MY.Lee, Association of serum uric acid concentration with diabetic retinopathy and albuminuria in Taiwanese patients with type 2 diabetes mellitus. Int J Mol Sci, Vol. 17, PP.220249, 2016.

[25] Y.Hayashino, S.Okamura, S.Tsujii, Association of serum uric acid levels with the risk of development or progression of albuminuria among Japanese patients with type 2 diabetes: a prospective cohort study [Diabetes Distress and Care Registry at Tenri (DDCRT 10)]. Acta Diabetol. Vol.53,PP.599607,2016 .

[26] IR.Reid Glucocorticoid effects on bone. J Clin Endocrinol Metab, Vol.83, PP.1860-1862,1998.

[27] H.Al-Majed, P.Jones, S.Persaud, , ACTH stimulates insulin secretion from MIN6 cells and primary mouse and human islets of Langerhans. Journal of Endocrinology ; Vol.180, PP.155-166, 2004. 